\section{DISCLAIMER}

This report was prepured as an account of work sponsored by an agency of the United States Government. Neither the United States Government nor any agency thereof, nor any of their employees, makes any warranty, express or implied, or assumes any legal lizbility or responsibility for the accuracy, completeness, or usefulness of any information, apparatus, product, or process disclosed, or represents that its use would not infringe privately owned rights. Reference herein to any specific commercial product, process, or service by trade name, trademurk, manufacturer, or otherwise does not necessarily constitute or imply its endorsement, recommendation, or favoring by the United States Government or any agency thereo: The views and opinions of authors expressed herein do not necessarily state or reflect thuse of the United States Government or any agency thereor.
\end{abstract}

CONF-900814--3

DE90 012802

\title{
THE ADVANCED NEUTRON SOURCE REACTOR: AN OVERVIEW*
}

\author{
Colin D. West
}

Oak Ridge National Laboratory

Oak Ridge, Tennessee 37831-8218, USA

\begin{abstract}
The Advanced Neutron Source (ANS) will be a new user facility for all kinds of neutron research, including neutron scattering, materials testing, materials analysis, isotope production and nuclear physics experiments. The centerpiece of the facility is to be the world's highest flux beam reactor. There will be beams of hot, cold and thermal neutrons for more than 40 simultaneous scattering and nuclear physics experiments. In addition, there will be irradiation positions and rabbit tubes for in-pile experiments, testing and isotopes production (including transuranium isotopes).
\end{abstract}

To reduce technical risks and to minimize safety issues, the reactor design is based on technology already employed in existing research reactors. The fuel elements are annular assemblies of aluminum clad involute fuel plates, similar to the design of the High Flux Isotope Reactor (HFIR) at Oak Ridge and the Institut Laue-Langevin (ILL) Reactor in Grenoble. As is common with many other research reactors, the core is cooled, moderated and reflected by heavy water. The preferred fuel is $\mathrm{U}_{3} \mathrm{Si}_{2}$ - a highdensity fuel form leveloped by Argonne National Laboratory and Babcock and Wilcox that has been extensively tested in reactors in the United States, Europe and Japan.

"Based on work performed at Oak Ridge National Laboratory, operated for the U.S. Department of Energy under contract DE-AC05-840R21400 with the Martin Marietta Energy Systems, Inc. 
A high flux beam reacior must have a compact core, and the consequential high power density requires particular attention to safety questions. Careful attention has been paid, from the beginning of the preconceptual design phase of the project, to safety questions. One example of this has been the development of a preconceptual design probabilistic risk assessment (PRA) that has already influenced the design concept. Several inherent aspects of the ANS contribute desirable safety features: the relatively low power level and fission product inventory (less than $10 \%$ of a typical power reactor); the large containment dome needed to house experiments around the reactor; design constraints which limit the coolant temperature to less than $100^{\circ} \mathrm{C}$ to eliminate any flarhing into steam on depressurization; and the small core with little stored energy. In addition, the design of the primary coolant system minimizes the potential for a pipe break to lead to loss-of-coolant, and the choice of an upflow coolant direction in the core enhances transition from forced-to-natural convection cooling.

Several features of the new facility will pose particular challenges in dosimetry. The experiments close to the core will experience very high neutron and gamma fluxes and very steep flux gradients, with spectra that change significantly during the 14-d core life. Totally internally reflecting neutron guides will be used to transport very intense beams of neutrons up to $100 \mathrm{~m}$ from the reactor and into an experimental area that can house 40 or more experiments and their users, with beams with as much as ten times more flux than existing reactors. Background radiation from these intense beams may change significantly as the experimental samples are moved or replaced, and protection of the users must be maintained at all times. The ANS Project would welcome early debate of these and other issues of dosimetry in a high fly research reactor facility.

\section{INTRODUCTION}

The Advanced Neutron Source (ANS) is a new facility for all kinds of neutron research, planned for construction at the U.S. Department of Energy's Oak Ridge National Laboratory. The major technical objectives of the project are

(1) to design and construct the world's highest flux research reactor for neutron scattering;

(2) to provide isotope production facilities that are as good as, or better than, the High Fiux Isotope Reactor (HFIR);

(3) to provide materials irradiation facilities that are as good as, or better than, the HFIR.

These technical objectives set the performance goals for the research reactor which will provide the source of neutrons (Table 1). A National Steering Committee for an Advanced Neutron Source (NSCANS), composed of neutron users from all fields of science, is also defining the needs in other areas, including materials analysis and nuclear 
physics. The reactor is only a part of the ANS facility, and NSCANS has also devoted a good deal of time to planning the neutron beam lines and instrument space that will be needed in the new facility (Figs. 1 and 2).

The peak thermal neutron flux in the reflector is an important measure of performance of a research reactor for beam work and helps to define the sensitivity and resolution of the research experiments that can be performed. The number of beams and the total number of neutrons delivered are a rough measure of the number of experiments that can be carried out, and they give some general indication of the scientific productivity that can be expected from a facility. In this respect, the plans proposed by our National Steering Committee will lead to a truly outstanding research capability (Table 2).

\section{Reactor Design}

To meet the performance criteria agreed upon by the scientific community, particularly for a thermal neutron flux available for neutron beams 5-to-10 times higher than the best existing facilities, we need a higher power and a higher power density than present research reactors. The essential requirement is a high thermal flux out in the reflector tank (i.e., outside the core) where it is accessible to beam tubes and guides for neutron scattering. The basis for the design is therefore a high power - to produce many neutrons - in a small, undermoderated core that will permit most of the fission neutrons to escape before they are thermalized. Thermalization takes place in a reflector surrounding the core. The coolant and the reflector should have low neutron absorption and should have a reasonably long slowing down length: in the case of the ANS reactor, and many other research reactors, this is achieved by selectıng heavy water as the coolant and reflector.

The combination of high power and a small core demands a design with a large cooling surface in a small volume and a fuel with high density and high thermal conductivity. The conceptual design for the ANS uses the thin, aluminum-clad, involute fuel plates that have proven so successful in, for example, the Institut Laue-Langevin (ILL) reactor and the HFIR. The reference fuel form is highly enriched $U_{3} S \quad i_{2}$ (for such a high flux reactor, low enriched fuel is not viable), with $\mathrm{UAl}_{\mathbf{x}}$ as a fallback alternative.

A new core geometry has been devised that is comprised of two coaxial annular fuel elements with different diameters, separated axially (Fig. 3). The arrangement combines the short heated length of the HFIR design with the greater "neutronic length" of the ILL core and offers a number of advantages. One advantage is that there is space around and inside the core with an appropriate spectrum for transuranium isotope production and materials irradiation capsules (Fig. 4).

In the reference design for ANS, the core is enclosed in a section of the primary coolant piping called the core pressure boundary tube (CPBT) which corresponds to the pressure vessel in a power reactor. There are two shutdown systems; one, which also 
provides control, is inside the core and the other is located in the reflector region outside the pressure boundary (Fig. 5).

The CPBT is surrounded by a large reflector tank of heavy water with space for beam tubes and two large, liquid deuterium cold neutron sources (Fig. 5). The cold neutrons are conducted to the guide hall area by means of cold neutron guides.

\section{Cooling System Design}

The reactor cooling systems are designed to make maximum use of passive features, for enhanced safety. There are four identical primary loops, of deliberately simple design with only one high point and one low point. In normal operation, three of the loops are in use. The design emphasizes natural convection for decay heat removal - for example, an upflow coolant direction through the core was chosen mainly to avoid any flow reversal during the transition from forced to natural convection. In addition, following each of the main heat exchangers is an emergency heat exchanger, immersed in a pool, for decay heat removal. The secondary side of the emergency heat exchanger is cooled by natural convection of the pool water (Fig. 7). Normally water entering the emergency heat exchanger is cool, and there is little driving force for natural convection through its secondary, but if cooling in the main heat exchanger were lost (although this is guarded against by the provision of battery-powered pony motors in addition to the main motors, on each pump), the emergency heat exchangers would automatically begin to provide passive cooling. Likewise, the cooling towers are elevated above the heat exchangers, so that in the event of a loss of pumping, natural convection would be available with the water in the seismically-hardened cooling tower basins as a heat sink. There is an independent secondary circuit for each of the primary loops.

To prevent loss of coolarit inventory in the event of a break or major leak in the primary circuit, most of the components are located under (light) water pools. The remainder are housed in limited volume dry cells: each of the primary loops has a gaspressurized accumulator containing five $\mathrm{m}^{3}$ of heavy water, enough to flood any one of the limited volume cells. The accumulator also slows down the rate of depressurization following a major leak or break, thus further protecting the core.

The design process has deliberately been organized and planned to emphasize safety. A key part of this approach has been the use of probabilistic risk analysis (PRA) techniques, even during the preconceptual design phase. Even in the absence of a detailed design for which quantitative calculations of risk can be made, the PRA approach provides guidance on the components and event sequences that can, through early design attention, lead to significant risk reduction. Some of the fruits of this powerful teshnique can be perceived in the previous description of the cooling system reference design, and there are many other examples. 
It is only within the last several months that the reference or baseline design features described earlier have been fixed. The next steps in the design process include trade-off studies to seek improvements in safety, per formance, or economics of the ANS.

\section{Dosimetry Issues}

A research reactor facility, and especially one designed as a user facility, poses particular challenges in dosimetry. Among the more obvious technical ones is the accurate measurement of the neutron flux and spectrum - both of which will vary during the operating cycle - at the in-core irradiation positions.

The ANS is intended as a user facility; we expect more than 1,000 users a year to come and carry out experiments, mainly beam experiments, when the ANS is fully operational, and many of these users will have had little or no training in a reactor environment. Radiation protection arrangements must be designed accordingly. The neutron guide tubes that are so essential to the research capabilities of the ANS also transport imense beams of neutrons up to $100 \mathrm{~m}$ or more away from the reactor core. Normally, few neutrons escape from the guide, but when an experimental sample is placed in the beam, then neutrons are scattered - indeed, the main purpose of most experiments is to measure the direction and energy of these scattered neutrons. Thus, the guide hall, which must be accessible to users, is a place of potentially significant background that may change from day to day or even from hour to hour. These effects are found at existing research reactor facilities of course, and appropriate measures have been taken. However, the beams at the ANS will be from 10 to 100 times more intense than at any present day facilities and may require new approaches. The control, measurement, and administration of radiation in the guide hall and other experimental areas is a matter that we believe should receive attention early in the design and planning of the ANS.

\section{CONCLUSION}

The Advanced Neutron Source facility will be a world class facility for neutron research, producing neutron beams an order or magnitude more intense than present facilities. A research reactor based on present day technology, and designed from the beginning with an emphasis on safety, will be the source of neutrons. To operate such a reactor as part of a user facility, while providing the necessary radiation protection and measurement capabilities, will require early attention to dosimetry issues.

\section{DISCLAIMER}

This report was prepared as an account of work sponsored by an agency of the United States Government. Neither the United States Government nor any agency thereof, nor any of their employees, makes any warranty, express or implied, or assumes any legal liability or responsibility for the accuracy, completeness, or usefulness of any information, apparatus, product, or process disclosed, or represents that its use would not infringe privately owned rights. Reference herein to any specific commercial product, process, or service by trade name, trademark, manufacturer, or otherwise does not necessarily constitute or imply its endorsement, recommendation, or favoring by the United States Government or any agency thereof. The views and opinions of authors expressed herein do not necessarily state or rcflect those of the United States Government or any agency thereof. 
Table 1. Some quantitative performance goals for the ANS reactor

Neutron beams

Peak thermal flux in reflector, $\mathrm{m}^{-2} \cdot \mathrm{s}^{-1}$

Thermal/fast flux ratio

$5-10 \times 10^{19}$

$\underline{\text { Materials irradiation }}$

Fast flux at irradiation positions, $\mathrm{m}^{-2} \cdot \mathrm{s}^{-1}$

Fast/thermal flux ratio

$\geq 1.4 \times 10^{19}$

$\geq 0.5$

Transuranium production

252 Cf production rate, $\mathrm{g} / \mathrm{y}$

1.5

254 Es production rate, microg/y

40 
Table 2. Capabilities (effective neutrons per second delivered to users) ${ }^{2}$

HFBR $^{\mathrm{b}}$

HFIR $^{c}$

$\mathbb{I L} \mathcal{L}^{\mathrm{d}}$

ANS $^{e}$

Hot

of

$0^{f}$

450

450

Thermal

350

400

1,000

11,500

Cold

30

$0^{t}$

700

16,000

Very cold

of

$0^{s}$

40

250

Ultra cold

of

$0^{t}$

450

2,800

A number of beams $x$ useful area of each beam $x$ peak flux in reflector $\left(10^{19} \mathrm{~s}^{1}\right)$.

40 MW operation.

'85 MW operation.

${ }^{\mathrm{d} B e a m s}$ available to users are overdemanded by about a factor of 4 .

'Minimum requirements assessed by the scientific community through four national workshops and by the National Steering Committee for an Advanced Neutron Source.

No sources for these beams are included in these reactors. 


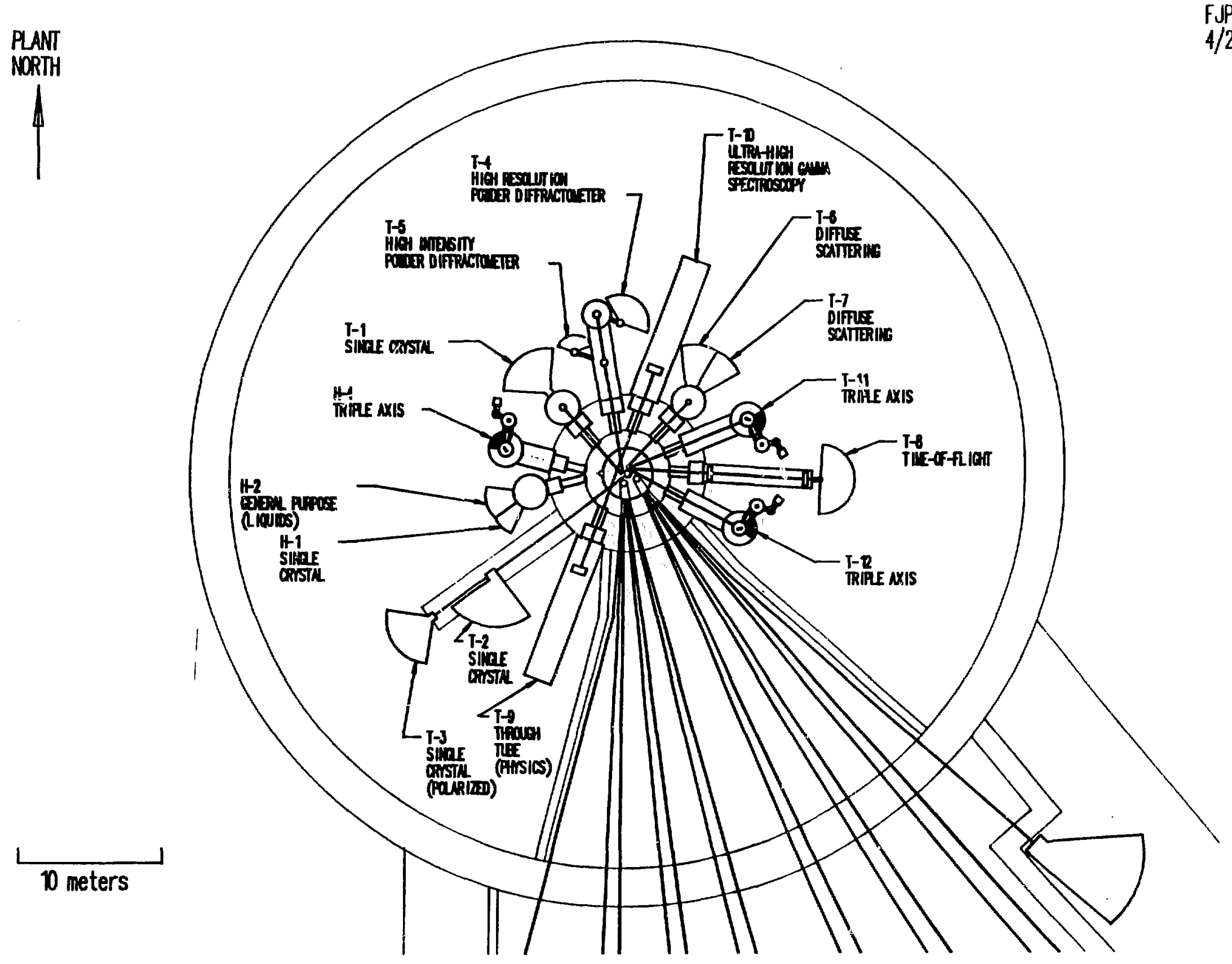

Fig. 1 Instrument layout on the thermal and hot neutron beam lines. 


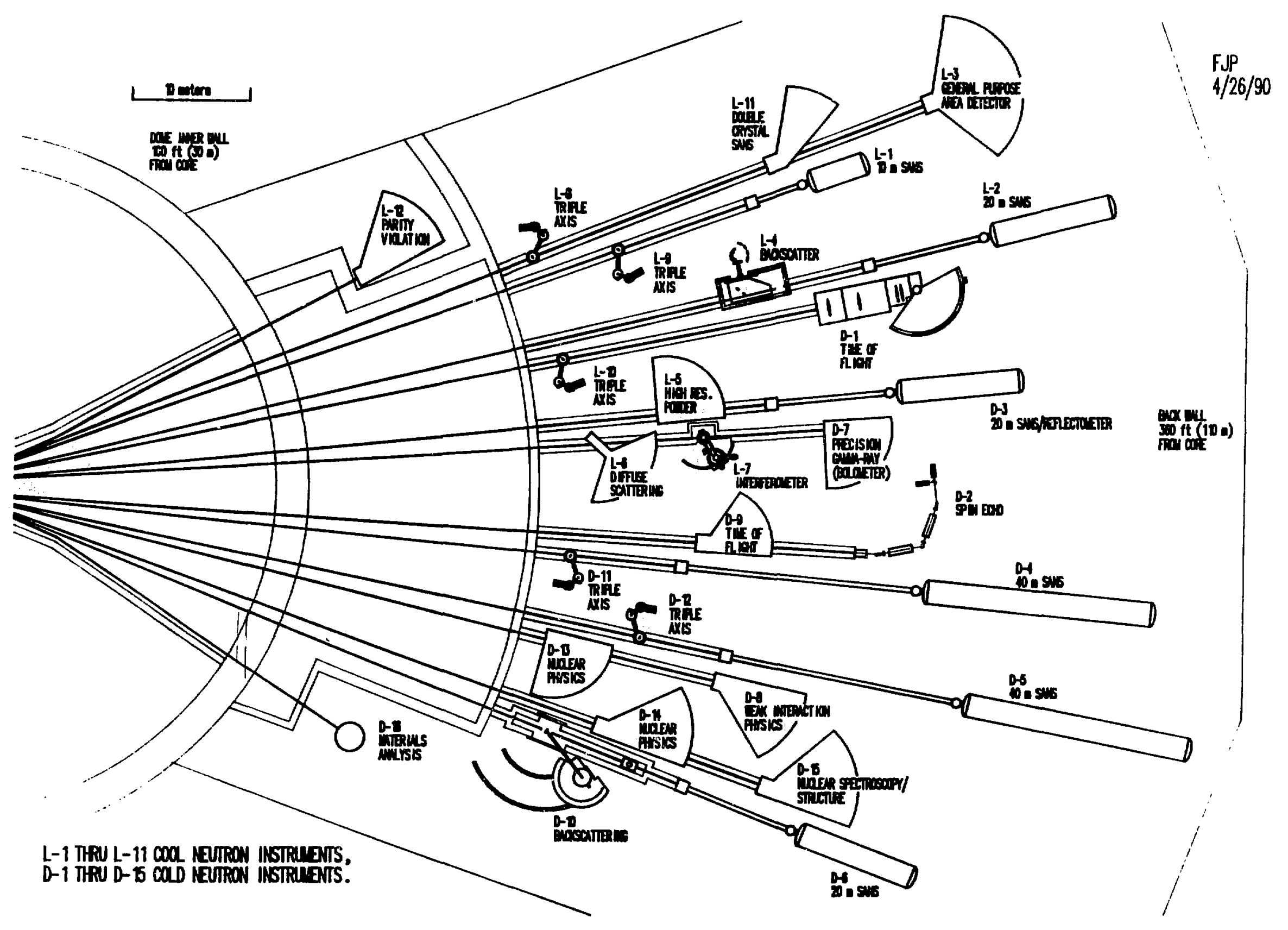

Fig. 2 Instrument layout on the cold neutron guides. 
The ANS Reactor Core Design Combines The Best Features Of Earlier Designs

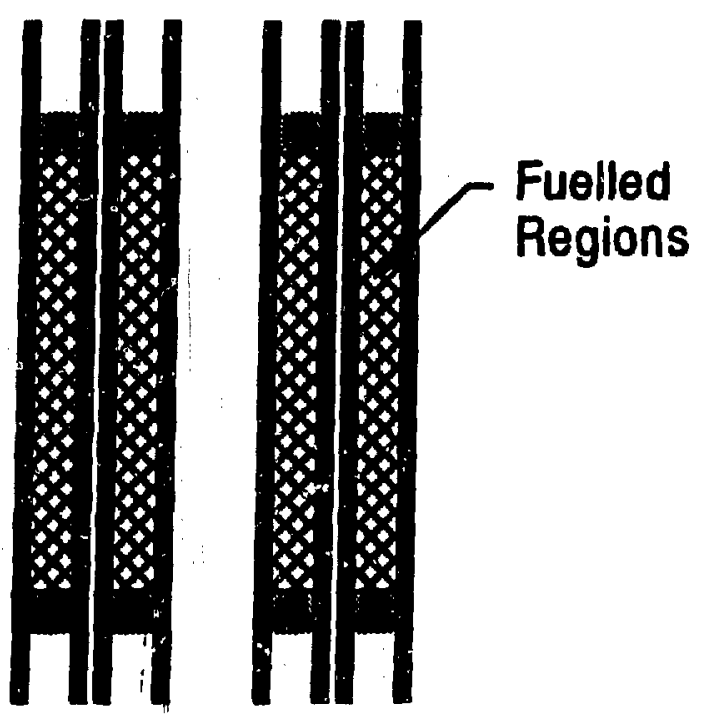

HFIR Core (Downflow)
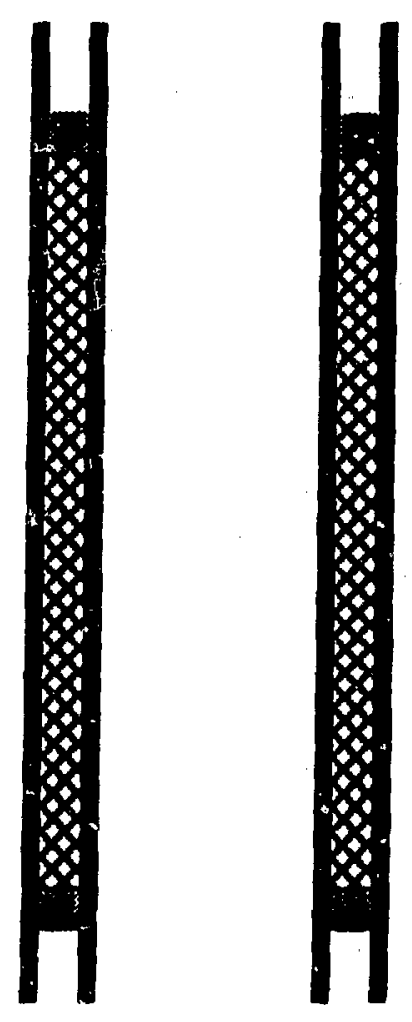

ILL Core (Downflow)
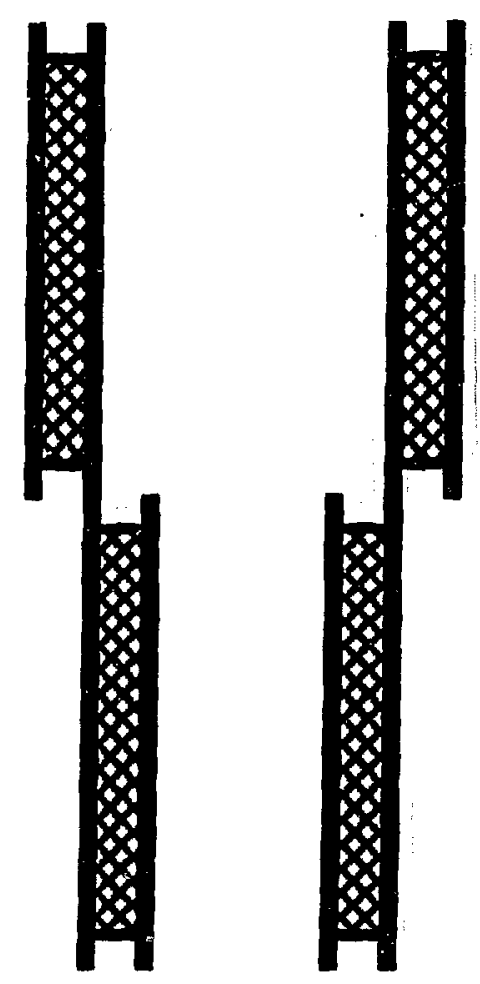

ANS Core (Upflow)

Fig. 3 


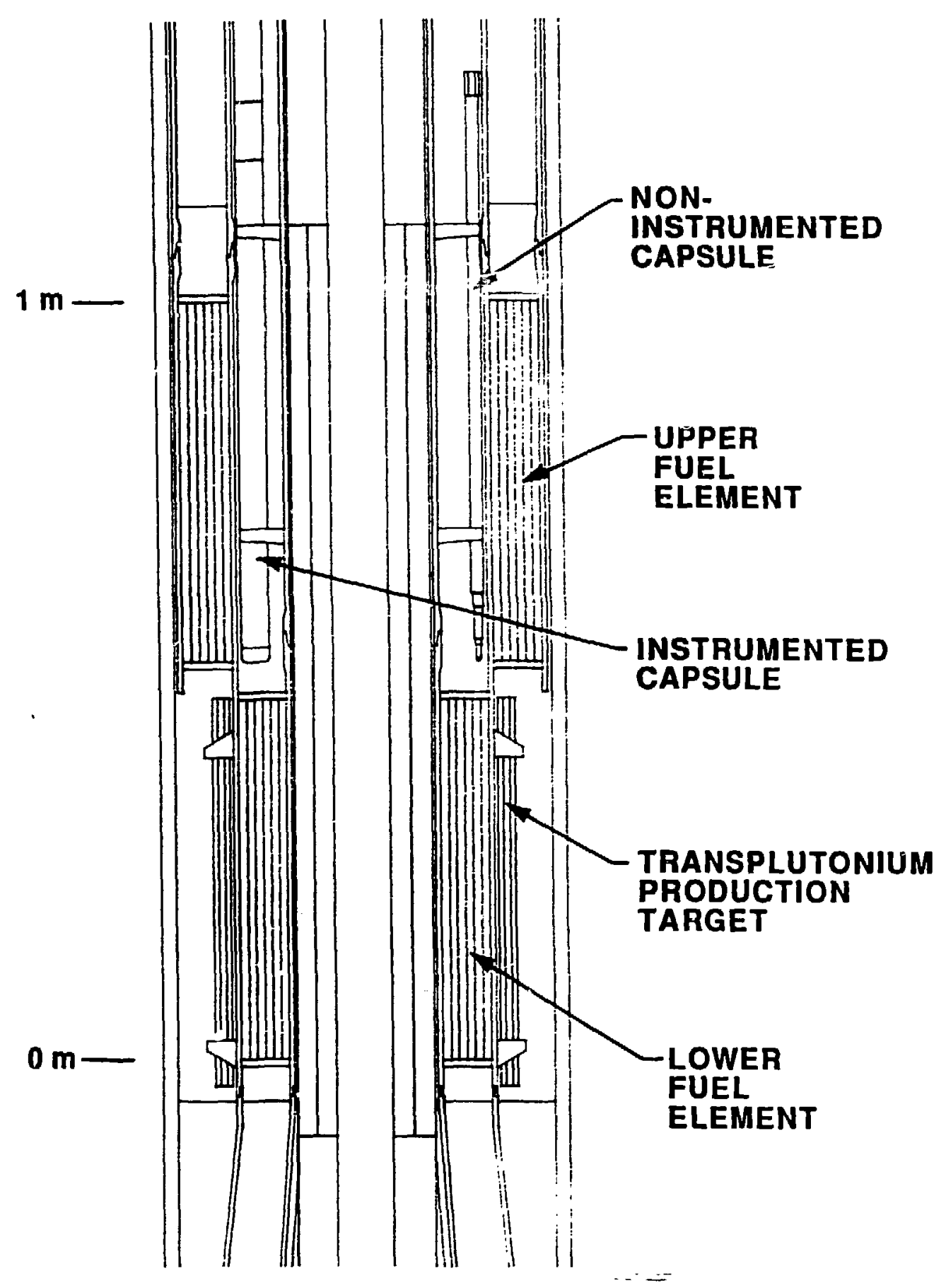

Fig. 4 ANS reactor core design showing materials irradiation capsules and transplutonium production target positions. 


\section{REFERENCE CORE DESIGN}

- The Project Has Devised An Improved Research Reactor Core Arrangement, With Two Annular Fuel Elements Of Different Diameters

- The Arrangement Offers Many Safety And Performance Advantages

- The Design Continues To Use The Well-proven Fuel Assembly Technology From Existing Reactors

- Two Separate, Diverse, Fast Shutdown Systems Arc Incorporated: One (Also Used For Control) Inside The Core And One Outside The Primary Coolant Syste m In The Reflector Tank

- Either System Alone Can Safely Sìut Down The Reactor, Even With One Rod Stuck

This Arrangement Leads To Reduced Probability Of Anticipated Transient Without Scram (ATWS)

Fig. 5 
Fig. 6 The reactor core is surrounded by a large, low-pressure tank of heavy water containing beam tubes, cold sources and isotope production facilities.

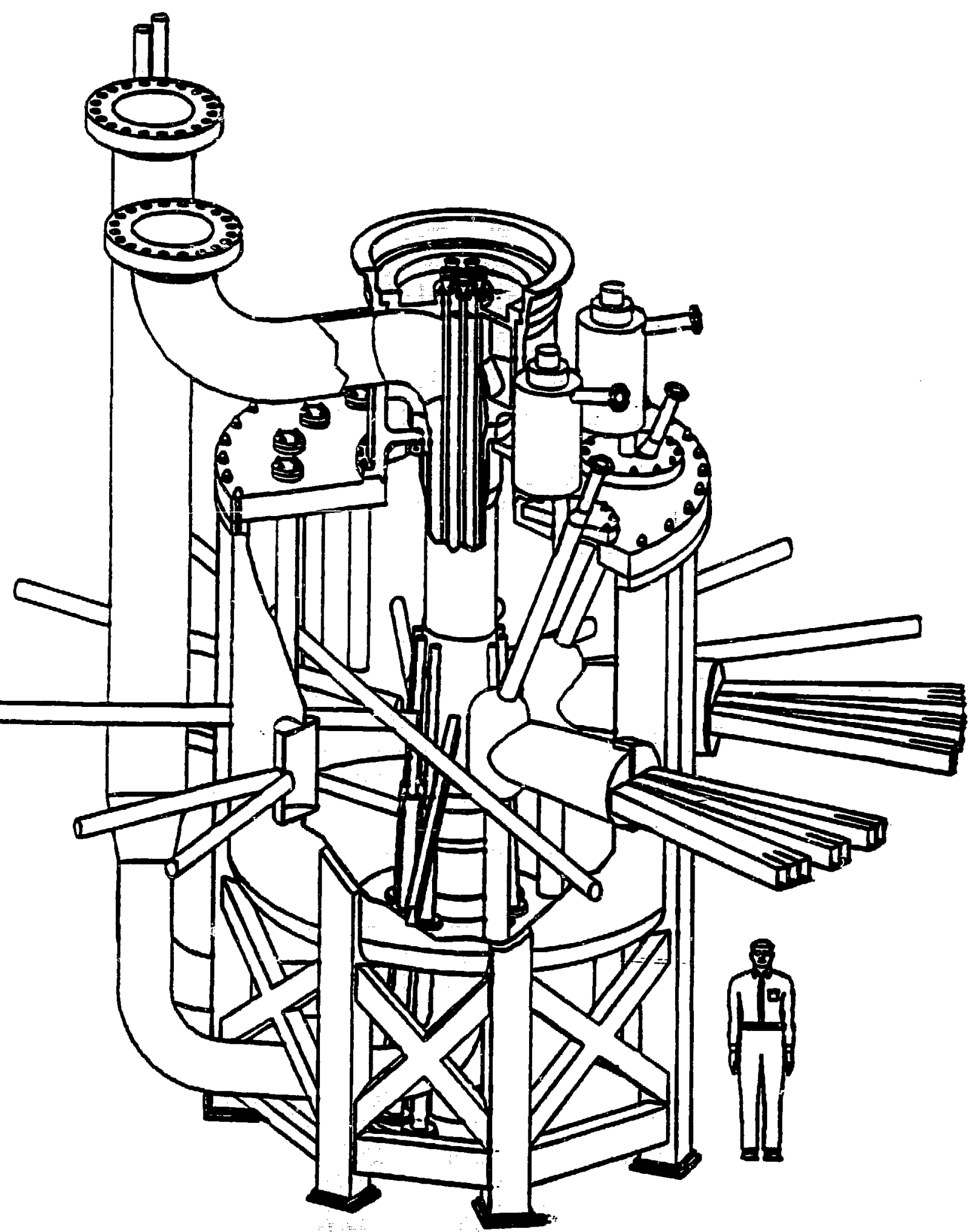


Fig. 7 There are four separate cooling circuits, designed to optimize reactor safety. Three are in use during normal operation.

REACTOR COOLING SYSTEM FIOWSHEET

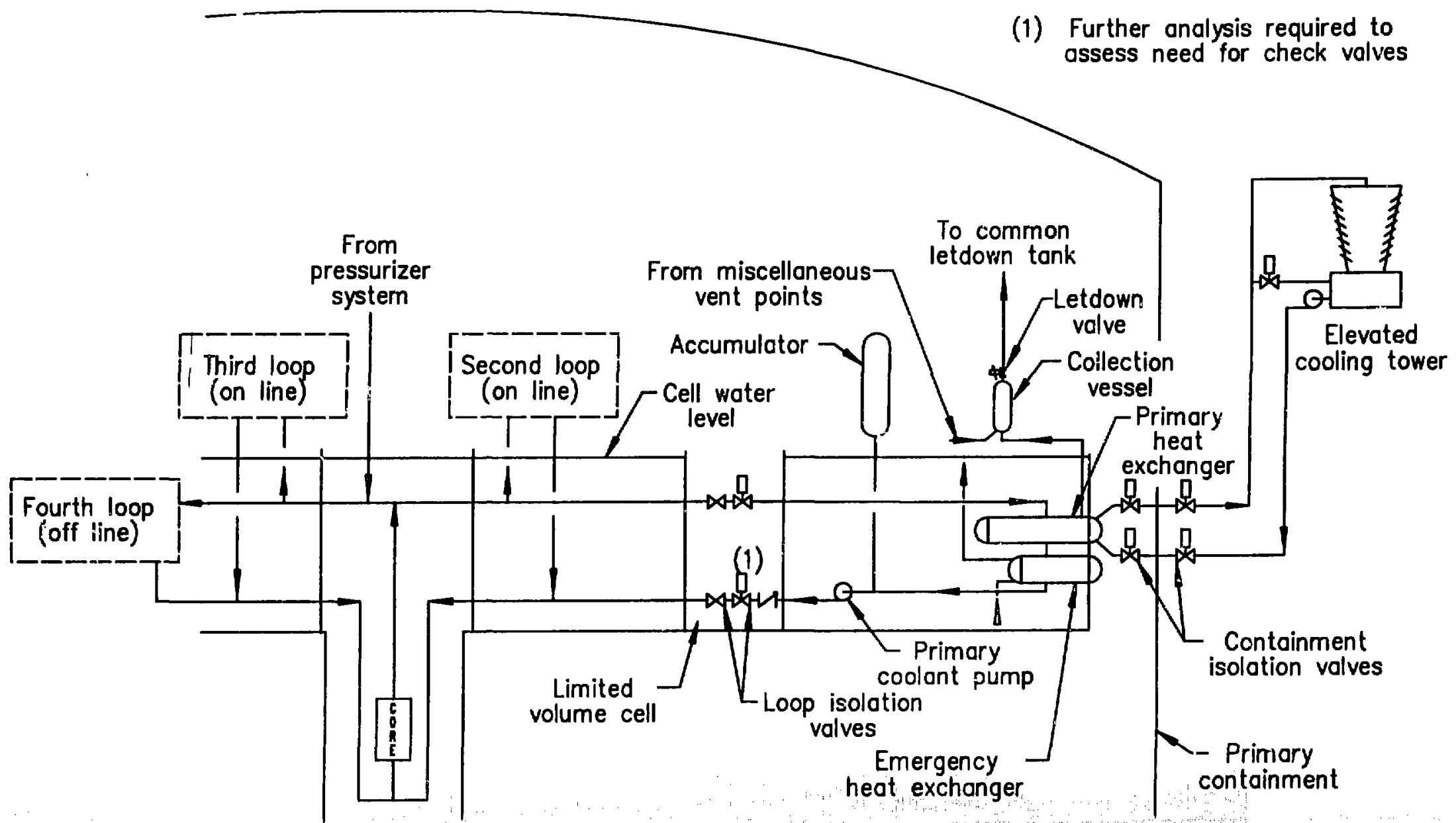

